\title{
Communication Strategy of Professional Investigators and Safeguards (Propam) in Interrogating Police Problems in the Police Medan city
}

\author{
Syukur Kholil ${ }^{1}$, Ahmad Thamrin Sikumbang ${ }^{1}$, Afriadi Amin ${ }^{2}$ \\ ${ }^{1}$ Lecturer in State Islamic University of North Sumatera (UINSU), Medan, Indonesia \\ ${ }^{2}$ Ph.D Student in State Islamic University of North Sumatera (UINSU), Medan, Indonesia
}

\section{Abstract}

This research discusses; 1) cases of violations committed by members of the Indonesian National Police in Medan District Police 2) the communication strategy of Propam investigators in interrogating violations committed and; 3) the effectiveness of the communication strategy applied. Using qualitative research, data is collected through observation, in-depth interviews, and document studies. Data were analyzed using Miles and Huberman analysis. The results of the study revealed that during 2018 there were 116 cases of violations committed by members of the Indonesian National Police in the Poltabes area of Medan. To uncover the motives of the violation cases, Propam investigators use two communication strategies, namely persuasive communication and human communication. Two strategies are used, which are effective in uncovering the motives of cases of violations committed by members of the National Police in the Polrestabes area of Medan.
\end{abstract}

Keywords

\section{communication}

strategies; propam;

problems; national

police

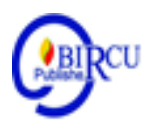

\section{Introduction}

Investigation is an activity carried out to find the meteril's truth. Investigations are carried out by police institutions and those who carry out such investigations are termed investigators. The police conduct investigations into violations committed by the general public and members of the National Police. Investigation of troubled police officers was carried out specifically by the Propam Division (Professional and Security).

In accordance with the observations made, Propam in Medan Polrestabes conducted an investigation of cases of violations committed by members of the National Police. Cases are handled professionally and proportionally according to the type of violation committed. Propam applies a communication strategy to explore deeply the motives of the violations committed. The communication strategy is different, because the characteristics of the police officers being investigated vary in terms of rank and case.

Communication strategy is a series of activities which include planning a series of activities that are designed with different techniques and approaches. As Effendy explained, "Engineering is a skill or skill that aims to inform, educate, entertain and influence". ${ }^{1}$ Thus, when communication techniques are carried out correctly, communication effectiveness will be achieved. Mulyana said, "The effectiveness of communication is the ultimate goal of interaction or communication. The effectiveness of communication is very dependent on the

\footnotetext{
${ }^{1}$ Onong Uchjana Effendy, Ilmu, Teori dan Filsafat Komunikasi (Bandung: PT. Citra Aditya Bakti, 1993), p, 55.
} 
use of language, communication style, body style when communicating, environment and time". 2

Observing the above opinion, it is clear that communication strategies and techniques are very urgent to be mastered by every Propam personnel in carrying out their duties as investigators. As the executor of the task or interrogator of problems at the National Police, Propam personnel communicate with different techniques according to the case at hand. This article will elaborate more deeply on the communication strategy carried out by Propam in conducting investigations of members of the Indonesian National Police who committed violations at Medan Regional Police.

\section{Research Method}

This research is a qualitative research that aims to systematically describe the facts or characteristics of certain populations factually and accurately. ${ }^{3}$ Lincon and Guba call it naturalistic inquiry, because the object under study is understood as it really is through natural analysis. ${ }^{4}$ The data in this study consisted of two types, namely primary and secondary data.

Primary data are collected through in-depth interview techniques with key informants selected by purposive sampling. Data collection techniques are also carried out through observation and study of documents relevant to the research topic. Data were analyzed by referring to the Miles and Huberman analysis technique, which starts from data reduction, which is to sort out and simplify the data, so that relevant data will be described to the results of the study. Present data to make it easier to analyze the absence of data and draw conclusions.

\section{Discussion}

\subsection{Overview of Cases of Violations by National Police at Polrestabes Medan}

Crime is not only committed by the general public, but is also carried out by unscrupulous members of the police, even though the police are law enforcers, protectors, patrons and public servants. Violations committed by members of the National Police have occurred for a long time and tarnished the authority of the police. Overcoming this problem, the National Police continues to take preventive measures (prevention) so that violations do not occur and curative efforts (to overcome those that have already happened) by providing sanctions and coaching for perpetrators.

Based on documents belonging to Medan Propam Polrestabes, there were 116 cases of violations committed by members of the Indonesian National Police during 2018. Types of violations committed were of three kinds, namely: First, disciplinary violations such as not entering service when the relevant Police were on duty. Second, the abuse of narcotics and illegal drugs. Third, family problems such as family neglect or domestic violence (domestic violence).

Some of these violations were reported directly by the public through the complaints service (Yanduan), some were complained by members of the Indonesian National Police

\footnotetext{
${ }^{2}$ Deddy Mulyana, Komunikasi Efektif (Bandung: Remaja Rosdakarya, 2004), p. 1.

${ }^{3}$ Jalaluddin Rakhmat, Metode Penelitian Komunikasi Dilengkapi Contoh Analisis Statistik (Bandung: Remaja Rosdakarya, 1984), p. 22.

${ }^{4}$ Yvonna S. Lincoln and Egon G. Guba, Naturalistic Inquiri (California: Sage Publications, 1985), pp. 70-91.
} 
themselves and some were also caught during a joint raid carried out by the Medan District Police and the TNI. Each report is followed up by the Propam Division to be investigated, so that the motive for the violation is known with certainty.

According to Mazlan Caniago, many violations committed by members of the National Police in the Medan Polrestabes area were caused by low motivation to work, and weak awareness in upholding the good name of the corps so that training was needed.

"Actually, there are a lot of problems that occur in members of the Polri in Medan Polrestabes. Among the most common cases were the number of members who did not enter service, drug use, acts of domestic violence and others. They explained a variety of reasons if asked why they did not go into service. There are reasons made up and there are also reasons that are indeed acceptable. Drug problems, a few years ago there were more than 150 drug users. This was caused by the lack of awareness among members to uphold the good name of Korsp. To overcome these problems, we from Propam continue to provide guidance and provide sanctions for perpetrators, so that violations do not repeat the reputation of the institution." 5

The information above shows that each member of the National Police is required to obey the code of ethics of the National Police profession, and those who violate will be disciplined. The four ethics in question are: First, personality ethics is related to the moral attitude of Polri members in upholding their profession. Secondly, the ethics of statehood is a moral attitude of members of the National Police who uphold the ideological and constitutional foundation of the Republic of Indonesia. Third, institutional ethics, namely the moral attitude of Polri members to uphold the dignity and dignity of the institution that serves as a forum for their service. Fourth, the ethics of relations with the community is the moral attitude of the police officers who always provide the best service for the community. ${ }^{6}$ Violation of the four ethics is a violation of the code of ethics that must be accounted for in the Polri Code of Ethics Commission hearing.

\subsection{Communication Strategy of Propam Investigators in Investigating Cases of Troubled National Police}

Propam's duty is to conduct an investigation of violations committed by members of the National Police. Investigation activities cannot be separated from communication activities, so investigators are required to have the ability to master communication strategies, because the investigators are fellow members of the National Police. Communication strategies such as certain communication techniques can be used to extract information from suspects. If the communication strategy chosen is inappropriate, the communication effect may not be achieved. Investigators can even find it difficult to obtain the information needed so as to hamper the smooth examination.

Based on the results of interviews conducted with Jhoni Panjaitan, a communication technique used by Propam investigators to uncover cases of violations committed by members of the Indonesian National Police in Medan Polrestabes in accordance with established SOPs. This was explained by Jhoni Panjaitan;

\footnotetext{
${ }^{5}$ Mazlan Chaniago, Bag Ops Polrestabes Medan, wawancara di Medan tanggal 12 Mei 2019.

${ }^{6}$ Regulation of the Head of the Indonesian National Police (Kapolri) Number 7 of 2006 concerning the Professional Code of Ethics of the Indonesian National Police.
} 
"During the interrogation, Propam investigators never carried out violence. If yelling to confess, it's normal. Because the character of the perpetrators is different. But even though there was shouting, it did not mean that the interrogation was accompanied by violence. We strongly safeguard humanitarian ethics while carrying out investigative duties. There is an SOP of investigation and should not be too far out of the SOP. So the image that has developed so far outside, if it has already entered Propam, will be forced to confess in harsh ways. That's a bad judgment. Get used to it, maybe someone feels that way, but it doesn't. We convey to every investigator to use humane methods. The methods of investigating Medan Polrestabes when interrogating a suspect were as follows: a. Look for the background of the suspect's life; b. Ask the circumstances of the suspect; c. Use language that is easy and understandable; d. Maintain ethics and courtesy in speaking; e. Do not use violence; f. Observe the body language of the suspect; g. Communicating from heart to heart; h. Regard suspects like family or friends; i. Give advice that can raise awareness."7

In accordance with the information conveyed by Jhoni Panjaitan, it can be understood that there are two kinds of communication techniques used by Propam in interrogating suspects, namely persuasive communication techniques and human communication techniques.

First, persuasive communication techniques. Persuasion or in English is called persuation which comes from the Latin word persuatio, meaning to persuade, things that invite or convince ${ }^{8}$. So in interrogation activities, persuasion is carried out to persuade and influence the examinee, so that they open themselves honestly about the problems that cause themselves to violate the rules.

Persuasion is carried out to uncover facts, without coercion. To carry out persuasion, the message is tailored to the conditions of the person being spoken to. In the process of persuasive communication, the ability to persuade individuals at the same time must be stimulated by messages that can influence the communicant. Efforts that can be made in persuasive communication are preparing messages that can arouse the communicant's attention. For persuasive communication to function properly and effectively, persuasion messages must be accompanied by a style that is impressive, charming, and not boring. ${ }^{9}$

The persuasive communication carried out by Propam in the investigation was accompanied by advice aimed at making people aware of and motivating violators. The information was obtained from Faisal Arisandi, based on the results of interviews conducted:

In conducting investigations, we emphasize with a persuasive approach, we always treat members with problems. It's like we treat our own family and close friends. We also realize that all human beings make mistakes. Today maybe he was caught making a mistake, but it is also possible in the day to come we might make the same mistakes. Therefore we also give good advice to every member who has a problem, who knows with the advice given they are aware and aware and promise not to repeat the same mistakes in the future. ${ }^{10}$

\footnotetext{
${ }^{7}$ Jhoni Panjaitan, Kanit Provos Polrestabes Medan, Wawancara in Medan 9 July 2018.

${ }^{8}$ Onong Uchjana Effendy, Dinamika komunikasi (Bandung: PT.Remaja Rosdakarya, 2004), p. 21.

${ }^{9}$ Dedy Djamaluddin Malik dan Yosal Iriantara, Komunikasi Persuasif (Bandung: PT. Remaja Rosdakarya, 1993), pp. 2-5.

${ }^{10}$ Faisal Arisandi, Baur Paminal Professional and Security Division Unit Polrestabes Medan, interview in Medan 22 August 2018.
} 
In accordance with the observations made, the Medan Proprest Polrestabes investigators conducted investigations using polite languages, such as saying "Good morning, good afternoon, or good afternoon". The language used by investigators is straightforward and easily understood by the examiner. Perpetrators of violations are treated humanely, there is no element of violence and intimidation that causes the examinee to feel threatened. The words conveyed politely, and in accordance with SOPs that have been set.

Second, human communication techniques (human communication). Medan Polrestabes Propam Investigators conduct interrogations on violators using human communication techniques. Human communication is communication that promotes respect for human values. Keith Davis explained, ethics and morals are the basis for human relations. So that someone feels valued, then humans do a variety of ways to do human relations. ${ }^{11}$

Propam uses human communication in conducting investigations of members of the Indonesian National Police who commit violations, as conveyed by Faisal Arisandi;

"We do not deny that there are very many cases of violations committed by unscrupulous members of the National Police in Poltabes Medan. Some of these cases were reported directly by the public, and some were arrested directly by Propam members. We treat them law fairly. They are members of the National Police, but they cannot be protected because they are wrong. They are police officers, we should make it harder for them, because it has damaged the positive image of the National Police. But we do not do that, because they are also human beings who are not free from wrong. We conduct interrogations in accordance with SOP. What is done to the general public, that's what we do to members who break the rules. We invite them to communicate well, and we treat them as they are as people who want to be respected. But we still carry out the interrogation according to the procedure. ${ }^{12}$

The ability to respect the human side, is an initial effort to be able to influence others. Recognizing the habits of others, recognizing their way of thinking and motivation and other human traits is an entry point to find out more about the human side of others.

Awareness of this must be embedded in an investigator. The ability of investigators to interrogate violations committed by members of National Police in Polrestabes Medan is not only based on scientific competence, main tasks and functions (tupoksi), but is based on other competencies, namely a good introduction to the humanity of others which is the basis of communication with them.

Enforcing justice in accordance with lawsuits, is one of the forms of respect for human values. In the perspective of Islamic communication, the Prophet Muhammad was sent by Allah to deliver messages of kindness to humanity in a fair manner, as well as in establishing a law. This is explained in the Koran surah An Nisa 'verse 58.

"Verily, Allah tells you to deliver the message to those who are entitled to receive it, and (tells you) if you establish a law between humans so that you determine it fairly. Surely Allah gives you the best teaching. Surely Allah is All-hearing, All-Seeing. ${ }^{13}$

\subsection{Effectiveness of Communication Strategies}

Effective communication according to McKenna means communicator and communicant both have the same understanding of a message being discussed. ${ }^{14}$ Goyer, as

\footnotetext{
${ }^{11}$ Keith Davis, Human Relations at Work (Singapore: Mc. Graw-Hill Book Company, Ltd, 1989), p. 26.

${ }^{12}$ Faisal Arisandi, Baur Paminal Professional and Security Division Unit Polrestabes Medan, interview in Medan 22 August 2018.

${ }^{13}$ QS. An Nisa/ 4: 58.
} 
quoted by Tubbs and Moss, explained that effective communication is communication that creates mutual understanding between the people involved in communication. In short, there is an agreement or what is called an equal agreement. ${ }^{15}$

Based on the results of the research conducted, two communication techniques carried out by Medan Propam Polrestabes investigators, namely persuasive communication and human communication, were able to uncover the motives of cases of violations committed by members of the National Police. The cases that were handled, some that continued in court because it was a serious violation such as drug use, and some came to the level of coaching, because it entered on minor violations such as not entering the official service hours as specified.

The effectiveness of communication is inseparable from the role of the communicator. Sendjaja explained, the effectiveness of communication is very closely related to the communicator that he divided into three characteristics, namely credibility, attractiveness, strength or power of the communicator. ${ }^{16}$

\section{Conclusion}

Communication is an instrument used by Propam investigators to conduct investigations of violations committed by members of the Indonesian National Police in Medan Regional Police. There are two kinds of communication techniques used by Propam to investigate violations committed by members of the Indonesian National Police, namely persuasive communication techniques and human communication techniques. Persuasive communication is carried out to persuade and approach violators, so that they consciously acknowledge the motives of the violations honestly. Human communication is intertwined through interpersonal communication while promoting respect for human values. Two communication strategies carried out by Propam investigators were able to uncover the motives of cases of violations committed by members of National Police in Polrestabes Medan.

\section{References}

Davis, Keith. Human Relations at Work. Singapore: Mc. Graw-Hill Book Company, Ltd, 1989.

Effendy, Onong Uchjana. Ilmu, Teori dan Filsafat Komunikasi. Bandung: PT. Citra Aditya Bakti, 1993. . Dinamika komunikasi. Bandung: PT.Remaja Rosdakarya, 2004.

Lincoln, Yvonna S. and Egon G. Guba. Naturalistic Inquiri. California: Sage Publications, 1985.

Malik, Dedy Djamaluddin dan Yosal Iriantara. Komunikasi Persuasif. Bandung: PT. Remaja Rosdakarya, 1993.

Peraturan Kepala Kepolisian Republik Indonesia (Kapolri) Nomor 7 Tahun 2006 tentang Kode Etik Profesi Kepolisian Republik Indonesia.

\footnotetext{
${ }^{14}$ Deddy Mulyana, Komunikasi Efektif (Bandung: Remaja Rosda Karya, 2008), p. 3.

${ }^{15}$ S.L. Tubss dan S. Moss, Komunikasi Antarmanusia: Prinsip-Prinsip Dasar, terj. Deddy Mulyana (Bandung: PT. Remaja Rosdakarya, 2000), p. 12.

${ }^{16}$ S. Djuarsa Sendjaja, Teori Komunikasi (Jakarta: Universitas Terbuka, 1994), p. 92.
} 
Mulyana, Deddy. Komunikasi Efektif. Bandung: Remaja Rosdakarya, 2004.

Rakhmat, Jalaluddin. Metode Penelitian Komunikasi Dilengkapi Contoh Analisis Statistik. Bandung: Remaja Rosdakarya, 1984.

Sendjaja, S. Djuarsa. Teori Komunikasi. Jakarta: Universitas Terbuka, 1994.

Tubss, S.L dan S. Moss. Komunikasi Antarmanusia: Prinsip-Prinsip Dasar, terj. Deddy Mulyana. Bandung: PT. Remaja Rosdakarya, 2000. 